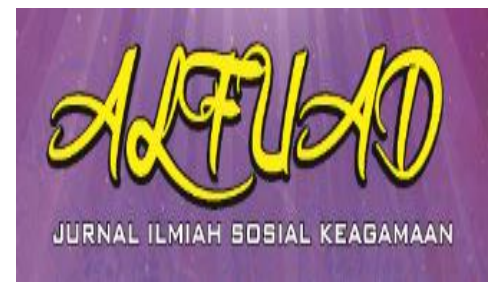

ALFUAD JOURNAL, 5 (2), 2021,(81-95)

(E-ISSN 2714-7606 P-ISSN 2614-4786 )

Available online at

http://ecampus.iainbatusangkar.ac.id/ojs/index.php/alfuad

\title{
The Position of Woman's Political Rights in Islam and The Indonesian Constitution
}

\section{Dewi Dahlan}

Institut Agama Islam Negeri Batusangkar, Indonesia

E-mail: $\underline{\text { dewidahlan@iainbatusangkar.ac.id }}$

\begin{abstract}
Women's political rights are often debated. Often deprived of women's rights. This is because women are often only involved in domestic or domestic matters. Basically, women's rights are the same as men's rights, including citizenship rights, education rights, opinion rights, and other rights. In connection with the position of women in obtaining political rights in the Islamic system and concept, it has been widely expressed. Some argue that Islam does not recognize political rights for women. There are those who view the same thing, there are also those who argue that Islam establishes and recognizes political rights for women except for being leaders of the state. This paper tries to describe the political rights of women in Islam and also explores the constitution of the Indonesian state. The method used is to conduct research on several literatures on politics in general regarding women's political rights and then compare them with one another.
\end{abstract}

Keywords: Woman, Political Rights, Position

\section{INTRODUCTION}

Political rights are rights that are determined and recognized by law or constitution based on membership as citizens. In general, the constitution links the fulfillment of these rights and the requirements of citizenship. This means that these rights do not apply except for local citizens, not foreigners. For example, the text of point I of the Law that regulates political rights in Egypt Number 73 of 1957 which reads, "Every Egyptian citizen, male or female, who is already ten years old $\mathrm{AD}$ automatically gets political rights. "The same thing is also stated in point 5 of the Parliamentary Law Number 38 of 1972 which was updated with Law number 109 of 1980 and point 75 of the local law number 43 of 1979 which requires the nomination or appointment of members in these assemblies must be individual citizens of Egyptian origin. As stated in the applicable law in point 75 , it is required that the person elected as president must be a person born to both parents who are Egyptian citizens.

In political rights, the concepts of rights and obligations are combined at the same time. Because political rights at a certain level become rights for individuals because those rights become obligatory for them. This is because the absolute right as 
accepted allows someone to use it or not to use it without any binding except in using it according to the constitution.

Meanwhile, if these political rights are not used in many law-making, it threatens to impose sanctions, especially because political rights do not apply except for people who meet certain conditions in addition to citizenship requirements.

These political rights imply the participation of individuals in the formation of public opinion, either in the election of their representatives in the assemblies and in various representative institutions or in their candidacy to become members of the assemblies or representative institutions. (Candrasi, 2020: 38)

These political rights include: first, the right to express opinions in elections and referendums in various ways. Second, the right in nomination to become a member of representative institutions and local institutions. The three rights in the nomination for president, and other matters that contain alliances and the expression of opinions related to politics. (Fauzi, Ikhwan, 2002: 120)

Regarding the position of women in obtaining political rights in the Islamic system and concepts have been widely expressed. Some argue that Islam does not recognize political rights for women. There are those who view the same between women and men in this matter. There are also those who argue that Islam stipulates and recognizes women's political rights except as leaders of the state. Meanwhile, there are other opinions which say that this problem is not a religious, fiqh or constitutional issue, but a social and political issue. Therefore, this issue is left to the social, political, and economic conditions of each country.

\section{METHOD}

For this paper, the author conducts research on some literature on Politics in general regarding Women's Political Rights and then compares them with each other. Then the author looks at the principles of Islamic teachings in general and relates them to Islamic teachings on ethics with all its scope. From this it is understood that Islamic political ethics is a study that is still not final and has that.

\section{RESULT AND DISCUSSION \\ Concerning Political Rights}

This opinion says that Islam does not stipulate equality between women and men, especially in obtaining political rights. This opinion is strongly supported by one of the Fatwa Lajnah Fatwa Al Azhar. Hujjatul Islam Abu Hamid Al Ghazali said that leadership (imamah) is not entrusted to women even though they have various perfections and independence. How women run for 
leadership positions, when she does not have court rights and testimony in many laws. As stated by al Qalqasyandi, "leaders (imam) need to associate with people and consult with them in various matters. Women are prohibited from it. This i because women have a biological deficiency so they do not have the right to establish marriages and cannot be leaders of others. (Candrasi, 2020: 38).

The issue of women's rights in candidacy has two other dimensions, namely: first, women become members in parliament, and secondly, they participate in the election of parliamentarians. In order to understand the provisions in these two issues, the first of which contains authority in general affairs, it must be explained that there are two kinds of authority, namely general authority and special authority.

General authority is power in public affairs, such as the authority to make laws, decisions of court proceedings, implementation of law, and control over law enforcement. Special authority is the power to regulate certain issues, such as wills to young children, authority over assets, and waqf arrangements.

Shari'a provides opportunities for women in the second authority above. In that respect, he has the same power that men have, as well as the power to regulate his special interests. He also has the right to use his assets in buying and selling, grants, pawns, rentals, and so on. Her husband and anyone else have no right to interfere in this matter. The Shari'a empowered him all by guiding him to maintain his honor and position. (Umar, Nasaruddin, 2010: 137)

\section{Women's General Authority}

Among the most important things for parliamentarians is the authority to make laws and oversee their implementation. Islamic law only imposes it on men if certain conditions are met. Its application has been practiced since the emergence of Islam until today. There is no evidence that any of these general powers have also been entrusted to women, either alone or with men. In the early days of Islam, women were cultured and had virtues. Among them many have virtues over men, such as the mothers of the believers (Ummahat al-Mu'minin).

Meanwhile, there is also an invitation for the participation of women together with men in the public interest. Women do not demand participation in any of these powers, and this participation is not demanded of them either. If there is justification for that from the Qur'an or the sunnah, surely the implementation is left to men and women equally. (Candrasi, 2020: 103) 
Political Rights and Power Irritation

The originator of this opinion said, "because there is no Shari'a law that prohibits women from exercising political rights, it is wrong to try to solve this problem by considering it a religious or fiqh issue.

It is not correct to think that progress and civilization are realized by imitating certain electoral systems that give women the right to vote or other political rights. Progress and civilization are realized by adopting an electoral system or other legal systems that are more appropriate and compatible with social and political conditions. These conditions are certainly different due to differences in time and place. It is also wrong if this problem is solved on the basis of the nature of women and the main task of women, namely being a mother.

The originator of this opinion explained that if we look at the problem from this side, we simply put it in the scope of psychology, namely that first, the nature and main task of women is to become mothers, secondly, women who work outside the home have a negative impact on their psyche and personality. The three emotions play an important role in mobilizing rational activities and mental tendencies, if men's decisions are more influenced by ratios, women's decisions are more influenced by emotions. Fourth, there is no reason to deny that there are differences between men and women in terms of skill talents. Political activities naturally do not include areas of interest to women in general, but according to their nature, women are more inclined to the skills of literature, journalism, art, music, education, and social services. Fifth, some experts in western countries criticize women working outside the home. They think that social activities will reduce their attention to household matters and their children.

The originator of this opinion concluded that everything that psychologists said and observed by experts on this matter was true, no doubt. However, is this an appropriate reason to issue a law that prohibits women from working outside the home and exercising their political rights? This cannot be used as an excuse for prohibiting women from working and exercising their rights the politics. Such prohibitions and restrictions can only be based on the demands of social, economic and political conditions, and depend on public opinion and the principles of justice. We must not overlook the following. (Umar, Nasaruddin, 2010: 86).

First, if it is true in our view that it is forbidden for women to work because of the nature of women, then the principles of justice and equality also demand that men 
are prohibited from doing jobs that are only in accordance with the nature of women. In these jobs, women have advantages over men, such as language and journalistic skills, as well as jobs that require hands-on skills, such as releasing, making, arranging, and gathering small objects to form large units.

Second, the opinion that women work outside the home is contrary to their nature and main task, namely being a mother, because it generally has a negative impact on their soul and personality. However, we must not forget that this conflict does not occur in all occupations. But only in jobs that require a mother to have to leave the house for a long time because she has to work outside the house from morning to evening.

Third, we need to know that human nature is a complicated problem, not as easy as some people think. The female personality does not only follow the demands of her female nature. Rather, it follows certain conditions according to the current social and economic developments. Then don't forget that since ancient times women have worked on agricultural lands and others. In addition, there are several factors that encourage women today to work. These factors vary due to individual differences, conditions and culture prevailing in society.
Fourth, if the nature of womanhood makes emotions play a major role in influencing the ratio of women, then we must remember that it does not appear except in the state of perfect womanhood. Though there are many factors that can weaken the influence of women on women.

Fifth, with regard to women's political activities, the critics say that only a limited number of women are able according to their readiness, age and opportunity to engage in this political activity practically (through parliament or other political-related institutions). so that solutions must be sought according to social, political, economic conditions and public opinion prevailing at a certain time and place as well as the principles of justice. Most of them are people who are free from the duties of motherhood because they are old, widowed or have no children. (Fauzi, Ikhwan, 2002: 137).

Based on the description above, the originator of this opinion views that the right thing is to place this issue as a political problem. So that solutions must be sought based on social, political, economic conditions, general opinion prevailing at a certain time and place, as well as the principles of justice. In addition, we must remove from Islamic law or positive law all obstacles that hinder the path formed by environmental 
conditions and demands of the public interest.

Based on the description above, the originator of this opinion views that the right thing is to place this issue as a sociopolitical problem. So that solutions must be sought based on social, political, economic conditions, general opinion prevailing at a certain time and place, as well as the principles of justice. In addition, we must remove from Islamic law or positive law all obstacles that hinder the path formed by environmental conditions and demands of the public interest.

\section{Women Constitutional Right to Politics}

According to Nurul Candrasari (2020), we are familiar with the terminology of human rights and the constitutional rights of citizens, human rights are a legal and normative concept, which states that every human being has inherent rights. Meanwhile, the citizen's constitutional rights are all rights of citizens that have been guaranteed by law. Human rights, abbreviated as HAM, apply universally, anytime, anywhere, and to anyone. Human rights are basically inalienable, interconnected, and interdependent. Human rights are addressed to the state, meaning that the state must be present to protect, respect and fulfill these rights, as well as prevent violations or neglect of them. In Indonesia, human rights are guaranteed and listed in the 1945 Constitution so that they have become the constitutional rights of citizens. Thus, all human rights become the constitutional rights of citizens. However, not all constitutional rights are human rights. As an illustration, the right of every citizen to occupy a position in the government is a constitutional right, but it does not apply to anyone who is not a citizen. (Suari, Giri, 2017: 33)

Constitutional rights of women the law applies generally and does not recognize gender discrimination. What are the constitutional rights of citizens, it becomes the rights of men and women There are at least 27 constitutional rights contained in the 1945 Constitution which include three categories, namely civil rights, social rights, and political rights. Civil rights, including the right to recognition, guarantee, protection, and fair legal certainty, as well as equal treatment before the law, the right to freedom of religion, the right to freedom of association, assembly, and expression, as well as the right to be free from torture and slavery. Social rights, including the right to education, the right to participate in cultural life, the right to vote, and the right to determine. Political rights, including the right to vote and be elected, the right to participate in the government, the right to 
establish a political party, the right to get a position in the government, and the right to participate in supervising the running of the government.

Women's political rights in particular, related to women's representation in parliament and in government as the implementation of women's political rights, it also has a policy basis in the form of Presidential Regulation Number 2 of 2015 concerning the RPJMN, which is a development of Law No. 17 of 2007 concerning the 20052025 RPJPN. This Presidential Regulation mentions the increased representation of women in politics, including the decisionmaking process in the executive, legislative, and judicial institutions. Based on the direction of the 2015-2019 RPJMN, the Ministry of PPPA has issued Ministerial Regulation No. 10 of 2015 concerning the Grand Design for Increasing Women's Representation in the DPR, DPD, and DPRD. Other policy foundations related to women's representation in politics are Presidential Instruction No. 9 of 2000 concerning Gender Mainstreaming in National Development, Election Law No. 8 of 2012, and Law No. 7 of 2017 concerning Elections. In this regulation, efforts have been made to increase women's seats in parliament, by mentioning placing one female legislative candidate out of three on the list of candidates proposed by political parties. One of the indicators of sustainable development goals (SDG's) is to achieve 50:50 gender equality by 2030 .

This is intended so that women can be in line and equal with men in the political field. The representation of women in parliament, participation in national development, and important state decision-making are expected to raise optimism for the birth of policies that are oriented towards the realization of gender equality and justice, as well as to support the government in implementing the SDGs. This is an effort by the government to provide and ensure the fulfillment of women's political rights so that they are involved in developing the nation in a just manner. But unfortunately, until today the role and participation of women in various fields including politics and development is still low. (Umar, Nasaruddin, 2010: 37)

Political rights and reserved seats to increase the number of women's seats in parliament, of course, it cannot be separated from the policies of political parties. In my opinion, until today, political parties tend to not have clear alignments for women's seats in parliament. That is why the $30 \%$ representation of women has not been realized. Several countries have succeeded in implementing a reserved seat policy, namely that political parties have an 
informal women's quota policy. For example, the ANC in South Africa (30\%), the Labor Party in Australia, and PJ and UCR in Argentina. In the UK, the list for the labor party in 1997 doubled from 60 to 119 (Karam) and women have the opportunity to compete with male candidates in terms of opportunities to become members of parliament.

Indonesia should be able to implement an affirmative action mechanism by following other countries that have given more space to women. Indonesia is expected to be an example of how to give women constitutional rights in politics through the policies of political parties. The Pol which expressly regulates the presence of $30 \%$ women's representation starts from the party's daily management to the placement of women on the list of legislative candidates. In the future, it is hoped that there will be laws for political parties and elections that regulate the electoral system, electoral districts, and serial numbers, which provide more guarantees for the realization of a quota of women's representation of at least $30 \%$ in parliament. Simply put, it is the political parties that should be serious about providing reserved seats for their female cadres to sit in parliament

\section{Constitutional Rights of Indonesian} Women

Women's rights have been fought for since the 18th century, starting with the formulation of "feminism" by an English feminist, Mary Wollstonecraft. In Wollstonecraft's formulation, women's rights are analyzed and women's rights are limited to laws and customs (culture) related to the constitutional system of a country. Feminism, according to Wollstonecraft, has a perspective on the lack of education for women, so that they are unable to exercise their rights which are left behind by men. The role of women in the family at that time in exercising their rights, both as individuals (as citizens), as mothers, as wives, must be carried out within the framework of the national legal system of the country concerned (liberal feminism). in the fields of economic, social, cultural, civil and political which are the substance of the CEDAW Convention, it has been recognized by the international community, including Indonesia which has ratified the Convention in 1984 and is at the same time obliged to implement it.

After the ratification of the CEDAW Convention, the meeting of world women was continued in the Second Women's Conference in 1980 in Copenhagen, III in Nairobi in 1985 and in 1995 the IV in Beijing. The struggle of 
women and women activists around the world continues to be active in following world developments by participating in international meetings, such as the United Nations Conference on the Environment in Rio de Janeiro in 1992, Human Rights in 1993, Population and Development in Cairo in 1994 and other international meetings. 4 Wollstonecraft, Mary John Stuart Mill, 1792, A Vindication of The Rights of Women, London, Vol. 1, p. 8-11. 6 After the CEDAW Convention is ratified by the participating countries, the country concerned is obliged to periodically report the implementation of the CEDAW Convention in the form of a National Report to the Commission on the Status of Women (CSW), it turns out that discrimination against women in the world is still ongoing. (Puji Astuti, 2008: 106).

This was reported at the Women's Conference in Beijing in 1995. At the meeting it was agreed to issue the "Beijing Platform for Action" (BPFA), which criticized 12 critical areas facing women worldwide, such as women's rights in education, health, employment towards girls.

After the Beijing Declaration Platform for Action and Plan for Action (BPFA Action Plan) in 1995, the Commission on the Status of Women/CSW in 2000 in its 23rd session of the United Nations General Assembly reported on the progress of countries participating in the CEDAW Convention. Talking about the constitutional rights of Indonesian women. It is better to understand in advance what a constitution is. The term constitution comes from the word constituer (French) which means to form which in this case has the meaning of forming, organizing, and compiling a country.

In English the word constitute can mean lifting, establishing or compiling. Then in Dutch, the term constitution is known as gronwet which means the basic law. The term constitution generally describes the entire constitutional system of a country. The system consists of the rules that shape, regulate or govern the state. Based on the opinions of experts, there are two understandings or understandings of the constitution.

First, in a broad sense, the constitution is a whole of basic rules and provisions (basic law which includes written basic law and unwritten basic law governing a government held within a country.

Second, in a narrow sense, the constitution is a law the constitution, which is a document that contains the basic rules and provisions of a state's state constitution. The purpose of the constitution itself is to limit the powers of state administrators so that they cannot act 
arbitrarily and can guarantee the rights of citizens. The purpose of this constitution is an idea called constitutionalism. The purpose of constitutionalism is an idea that views the government as a collection of activities organized by and on behalf of the people. Besides that, there is also a function of the establishment of the constitution itself. The first function is to limit or control the powers of government. so that in exercising his power not arbitrarily against his people. Then the second function provides a framework and legal basis for the change in society that is aspired to in the next stage.

Third, the function of the constitution is as a structural basis for the administration of the state according to a certain administrative system which is upheld by all its citizens, both the rulers and the people. Apart from being juridical, the constitution also has sociological and political meanings. This means that the constitution reflects the socio-political life of a society as a reality. The 1945 Constitution of the Republic of Indonesia is a constitution that was born from the identity of the Indonesian nation as a whole and contains noble ideals. This view of life of the Indonesian nation is embodied in the formulation of the Pancasila precepts which are used as the philosophy of state life based on the 1945 Constitution of the Republic of Indonesia.
Pancasila in the context of national and state life exists as a philosophical philosophy and common platform to ensure togetherness in the life of the nation and state. in realizing common goals and aspirations.

Pancasila as the philosophy of national and state life became the philosophical foundations in the preparation of the 1945 Constitution of the Republic of Indonesia. It means that it is the law that actually governs or leads in a country, not humans or people. The function of a right according to the view of interest theory is to extend the interests of the right holder. According to this theory, a person has a right not because he has a choice, but because ownership makes the owner better off. The existence of rights based on this theory is not limited to statements caused by ratios. This theory knows no limits on what is entitled to become a candidate as a right holder because the theory sees everyone has an interest.

In contrast to the will theory which provides an understanding of rights as something that only exists if there is a clear right holder and has the authority to use or release it. The state is obliged to fulfill and protect the constitutional rights of citizens in the form of recognition of human rights, the existence of an independent judiciary that is not influenced by the authorities and 
all government actions must be carried out on a legal basis. Human rights are different from the rights of citizens because the rights of citizens only apply to citizens, while human rights apply universally. Human rights contained in the 1945 Constitution of the Republic of Indonesia can be said to be the constitutional rights of Indonesian citizens. This means that human rights are rights inherent in every human person that must be fully protected by the state as a human being. This is what distinguishes between human rights (the human rights) and the notion of the citizen's rights. Constitutional rights (constitutional rights) according to Prof. Jimly Asshiddiqie are rights that are guaranteed in and by the 1945 Constitution of the Republic of Indonesia.

After the amendment to the 1945 Constitution, the principles of human rights have been included as the main material. These principles form the basis of the constitutional rights of citizens which give birth to an obligation for the state to fulfill them. As a state of law, one of the absolute elements that must exist is the fulfillment of basic human rights and the protection of human rights. The guarantee of the protection of human rights in the constitution as the highest law means that the state is prohibited from violating human rights and even the main task of protecting human rights is the state.
Therefore, the main task of the state that obtains a monopoly of power from the people as the holder of the highest power is to fulfill and protect human rights. Constitutional rights are different from legal rights. Constitutional rights are rights that are guaranteed in and by the 1945 Constitution of the Republic of Indonesia, while legal rights are born based on the guarantees of the law and the legislation under it. Even after the amendment of the 1945 Constitution, Human Rights in Indonesia have been fully recognized and fulfill the requirements as a good constitution. Human rights and the rights of citizens can be related to the notion of "Constitutional Rights".

The implementation of these constitutional rights is further regulated in more detail in laws or other lower legislation. The Indonesian Constitution, namely the 1945 Constitution of the Republic of Indonesia (which has been amended four times) in it has regulated human rights in general and there are also arrangements regarding women's rights. Prior to the existence of the UDHR, Conventions, Covenants and other international legal instruments, Indonesia had made a pledge to establish the Constitution of the Republic of Indonesia, namely in the Preamble: That independence is the right of all nations and because of that, colonialism in the world 
must be abolished, because it is not in accordance with humanity and justice. This shows that at that time, human rights had been recognized and upheld so that they were included in the preamble to the Constitution. Also, we can see in Pancasila which is the ideology of the Indonesian nation, especially in the Second Precept, namely just and civilized humanity and the Fifth Precept, namely social justice for all Indonesian people.

The regulation regarding Human Rights in the 1945 Constitution of the Republic of Indonesia is contained in CHAPTER XA concerning "Human Rights", regulated from Article 28 A to Article 28 J. Human Rights which cover all areas of life, in marriage (Article $28 \mathrm{~B}$ In particular, children are given special arrangements for protection from violence and discrimination in paragraph 2), selfdevelopment (Article $28 \mathrm{C}$ ), recognition, guarantees, protection and fair legal certainty and equal treatment before the law (Article $28 \mathrm{D}$ ), free embracing religion (article 28 E), communicating and obtaining information (article 28 F), personal protection, family, honor and so on (article $28 \mathrm{G}$ ), living in physical and spiritual prosperity (article $28 \mathrm{H}$ ), right to life, right not to be tortured, and so on (article $28 \mathrm{I}$ ) and article $28 \mathrm{~J}$ which is the obligation of every citizen to respect the human rights of others. The constitutional rights of citizens which include human rights and the rights of citizens guaranteed in the 1945 Constitution of the Republic of Indonesia apply to every Indonesian citizen. This can be seen from its formulation which uses the phrases "everyone", "all citizens", "every citizen", or "every citizen", which shows that constitutional rights are owned by every individual citizen without distinction, whether based on ethnicity, religion, political belief, or gender.

These rights are recognized and guaranteed for every citizen for men and women. 11 Even the 1945 Constitution of the Republic of Indonesia also stipulates that "Everyone has the right to be free from discriminatory treatment on any basis and is entitled to protection against such discriminatory treatment". It can be concluded, if there are provisions or actions that discriminate against certain citizens, it violates the human rights and constitutional rights of citizens, and automatically contradicts the 1945 Constitution of the Republic of Indonesia.

Therefore, every female Indonesian citizen has the same constitutional rights as male Indonesian citizens. Women also have the right not to be discriminated against based on their status as women, or on the basis of other differences. All the constitutional rights that have been described previously are the constitutional 
rights of every woman Indonesian citizen. The protection and fulfillment of constitutional rights that are carried out without regard to the existence of these differences will automatically maintain and even further the differences. So that every citizen has the same ability and can obtain protection and fulfillment of the same constitutional rights, special treatment is needed for certain groups. Only with this special treatment can equal treatment be achieved in the protection and fulfillment of the constitutional rights of every citizen. Therefore, the 1945 Constitution of the Republic of Indonesia guarantees such special treatment as the right to obtain equal opportunities and benefits. Article $28 \mathrm{H}$ Paragraph (2) states "Everyone is entitled to special facilities and treatment to obtain the same opportunities and benefits in order to achieve equality and justice".

\section{Women's Representation in Politics}

The regulation regarding the mandatory 30 percent quota for female legislative candidates is one of the important achievements in Indonesia's post-reform democracy journey. These rules are contained in a number of laws, namely Law no. 31 of 2002 concerning Political Parties, Law no. 12 of 2003 concerning General Elections, Law no. 2 of 2008 concerning Political Parties and
Law no. 10 of 2008 concerning General Elections for Members of the DPR-DPRD which also contains regulations related to the 2009 Election.

UU no. 2 of 2008 mandates political parties to include a minimum of 30 women's representation in establishment and management at the central level. The figure of 30 percent is based on the results of a UN study which states that a minimum of 30 percent allows a change to occur and has an impact on the quality of decisions taken in public institutions.

UU no. 10 of 2008 requires political parties to include 30 percent of women's representation in the management at the central level. These conditions must be met by political parties in order to participate in the election. Other regulations related to women's representation are contained in Law no. 10 of 2008 Article paragraph 2 which regulates the implementation of the zipper system, that is, for every 3 legislative candidates, there is at least one female legislative candidate.

Although the representation of women in the political realm has been practically encouraged in such a way through various policies, the results are still far from satisfactory. According to data from the Inter Parliamentary Union (IPU), as quoted by Scholastica Gerintya 
(2017), at the ASEAN level, Indonesia ranks sixth in terms of women's representation in parliament. Meanwhile, at the international level, Indonesia's position is ranked 89th out of 168 countries, far below Afghanistan, Vietnam, Timor Leste, and Pakistan.

\section{CONCLUSION}

Concerning women's political rights in Islamic thought and modern law. It is clear to us that one of the rights of women is participation, on the basis of equality in building, managing, and developing the hidden potential of society. That is what requires women's participation in political activities. So Islam does not prohibit women from exercising these rights. On the other hand, Islam emphasizes that women may exercise these rights by imitating men. On the other hand, most modern laws also emphasize that women may exercise their political rights.

The marginalization of women's roles in women's contestation is basically a denial of human values. The public perception that women are domestic beings who do not fit into the world of politics absolutely must end. Likewise, religious interpretations that tend to identify leadership with masculinity should ideally be shifted to a more gender-sensitive perspective
Regarding the political rights of women in Islam, it is hoped that women can use their political rights such as participating in the rights to citizenship, the right to choose leaders and the right to express their opinions.

Regarding the marginalization of women in political contestation, it is hoped that the constitution can regulate more proportionally these women's rights such as women's representation in parliament and so on.

\section{REFERENCES}

Bari, F. (2010). Partisipasi Perempuand alam Politik dan Pemerintah, Jakarta: United Nation Development Programme (UNDP) Indonesia.

Basyaib, H. (2006). Membela Kebebasan Percakapan tentang Demokrasi Liberal. Jakarta: Pustaka Alvabet.

Budiardjo, M. (2008). Dasar-dasar Ilmu Politik. Jakarta: Gramedia.

Candrasi, N. (2020). Hak Konstitusi Perempuan Untuk Berpolitik. (https://mediaindonesia.com/opini/3 64020/hak-konstitusi-perempuanuntuk-berpolitik), diakses 10 Februari 2020.

Fauzi, I. (2002). Perempuan dan Kekuasaan (Menelusuri Hak Politik dan Persoalan Gender dalam Islam). Jakarta: Amzah.

Kiftiyah, A. (2019). Perempuan dalam Partisipasi Politik di Indonesia. Jurnal Yuridis, 6 (2).

Kania, D. (2015). Hak Asassi Perempuan dalam Peraturan PerundangUndangan di Indonesia. Jurnal Konstitusi, 12 (4). 
Fakih, M. (1996). Analisi Gender \& Transformasi Sosial. Yogyakarta: Pustaka Pelajar, 1996.

Astuti, P., \& Marhaeni, T. (2008). Citra Perempuan dalam Politik. Jurnal tudi Gender dan Anak, 1.

Giri, S. Ni Putu. (2017). Hak-Hak Konstitusi Perempuan di Indonesia. (https://simdos.unud.ac.id/uploads/fi le_penelitian_1_dir/d29a25bed0a35 ee9b2e2c6b4ce723436.pdf), diakses 10 Februari 2020.

Sanger, B. G. (2019). Perlindungan Hak Politik Perempuan Sebagai Hak Asasi Manusia dan Pengaturannya dalam Konvensi Internasional. Lex Et Societatis, 8 (3).

Tahqiq, N. (2004). Politik Islam. Jakarta: Prenada Media.

Umar, N. (2010). Fikih Wanita untuk Semua. Jakarta: Serambi.

Undang-Undang Nomor 7 Tahun 1984 tentang Pengesahan Konvensi Mengenai Penghapusan Segala Bentuk Diskiriminasi Terhadap Wanita (Convention on The Elimination of All Forms of Discrimanation Against Women); Lembar Negara 1984/29; Tambahan Lembar Negara Nomor 3277. 